\title{
Low-Temperature Performance of Al-air Batteries
}

\author{
Yuxin Zuo ${ }^{1}$, Ying $\mathrm{Yu}^{2, *} \mathbb{D}$, Chuncheng Zuo ${ }^{2, *}$, Chuanlong Ning ${ }^{2}$, Hao Liu ${ }^{2}$, Zhiqing Gu ${ }^{2}$, \\ Qianqian $\mathrm{Cao}^{2}$ and Ciming Shen ${ }^{2}$ \\ 1 College of Design, Jiaxing University, Jiaxing 314000, China; yuxinzuo@mail.zjxu.edu.cn \\ 2 College of Mechanical and Electrical Engineering, Jiaxing University, Jiaxing 314000, China; \\ ningchuanlong@outlook.com (C.N.); hliu@mail.zjxu.edu.cn (H.L.); guzhiqing111@mail.zjxu.edu.cn (Z.G.); \\ qqcao@mail.zjxu.edu.cn (Q.C.); happyciming@outlook.com (C.S.) \\ * Correspondence: yingyu@mail.zjxu.edu.cn (Y.Y.); zuocc@mail.zjxu.edu.cn (C.Z.)
}

Received: 3 January 2019; Accepted: 12 February 2019; Published: 15 February 2019

\begin{abstract}
High demand for batteries with a wide operating temperature range is on the rise with the development of wearable electronic devices, especially electric vehicles used in cold regions. Al-air batteries for electric vehicles have triggered worldwide interest due to their excellent theoretical energy density and safety. In this study, the low-temperature performance of Al-air batteries is tested for the first time. The effects of temperature and electrolyte concentrations on the discharge performance are then studied in detail. The discharge voltage is significantly influenced by the temperature. The low temperature could significantly depress the hydrogen evolution reaction of $\mathrm{Al}$ anodes. The Al-air batteries reached an extraordinary capacity of $2480 \mathrm{mAh} / \mathrm{g}$, with $31 \mathrm{wt} \% \mathrm{KOH}$ electrolyte at $-15{ }^{\circ} \mathrm{C}$. Moreover, the $\mathrm{Al}-$ air batteries at $0{ }^{\circ} \mathrm{C}$ exhibited higher discharge voltage and power densities than those at 15 and $-15^{\circ} \mathrm{C}$. This study provides an important reference for future studies to improve low-temperature performance of Al-air batteries.
\end{abstract}

Keywords: al-air battery; low temperature; discharge performance

\section{Introduction}

Besides the rapid advancement of modern industrial technology, other factors, such as environment friendliness, cleanliness, and being an alternative inexpensive energy source have become the subject of research because of the limitations of traditional energy, i.e., fossil fuel exhaustion and risk of climatic degeneration [1]. Metal-air batteries are one of the most promising candidates for next-generation energy storage due to their high capacity and energy density. Al-air batteries have driven the increasing concern due to their high specific energy density, low cost [2], and stability in solid gel electrolyte [3] or the electrolyte with additives (such as $\mathrm{ZnO} / \mathrm{PEG}$ di-acid inhibitor and non-conductive oil) $[4,5]$. The application of these batteries has spread to remote communications, railroad signaling, seismic telemetry, and power grids. Moreover, the high safety and long platform of discharge make them a prominent power storage source for hybrid electric vehicles [6,7]. Although significant progress has been achieved in enhancing the electrochemical performance of Al-air battery, a critical issue that seriously restricts its future commercialization and practical application remains. Batteries are sensitive to environmental conditions, especially to temperature. However, few studies focus on low-temperature (LT) performance of Al-air batteries, which is of considerable importance for the development of Al-air battery. For example, understanding the effects of winter operation for electric vehicles is critical in cold regions, such as Switzerland, Canada, Northern USA, Northeast China, and Russia.

Scientists have already realized that a broad application temperature range is a big challenge for battery development. Numerous papers have addressed the problem of poor LT performance of 
various kinds of batteries [8-13]. If the temperature falls to the subzero range, then the electrochemical performance and stability of batteries can be dramatically reduced, depending on the battery chemistry in comparison with those at room temperature. Ji et al. [14] have shown that the sluggish diffusion process of ions at LT leads to the remarkable deterioration of electrochemical performance. For vanadium redox flow batteries, a relatively low energy density is limited by the solubility of vanadium ions in the sulfuric acid supporting electrolyte at LT [15]. The high capability and cycling stability of Na-ion batteries are substantially reduced when temperature falls below $0{ }^{\circ} \mathrm{C}$ [16]. Most studies focused on the LT performance of Li-ion batteries, particularly for propelling electric vehicles [11,17-19]. Some studies suggest that discharge capacity and operating voltage are limited by the poor ionic conductivity of electrolytes and low diffusivity of lithium ion within graphite anodes at LT. A study reported that Li-ion batteries could only deliver $5 \%$ of its capacity at $-40{ }^{\circ} \mathrm{C}$ compared with that at $20{ }^{\circ} \mathrm{C}[12,20]$. Researchers focus on improving battery cycling stability and capacity at LT [14,21-28]. Al-air batteries exhibits evident advantages over Li-ion batteries. Al-air batteries are safe and cost effective, and their raw materials are widely available. These advantages demonstrate that the Al-air battery has the potential to be a backbone technology for the energy storage of electric vehicles in the future. However, the LT performance of the Al-air battery has never been tested or investigated. Therefore, studying the mechanisms of LT performance for the Al-air battery is crucial and challenging.

Based on the aforementioned reasons, the LT electrochemical performance for Al-air batteries is comprehensively tested in this study. The following section presents a detailed fabrication of the $\mathrm{Al}$-air battery. In addition, the electrochemical performance is tested and discussed. The results could provide suggestions for developing better-performing $\mathrm{Al}$-air batteries.

\section{Experiment}

\subsection{Materials}

All materials in this study were of analytical grade and used without further treatment. Reagents for the air cathode synthesis, including activated carbon, ether black, poly(vinylidene fluoride) (PVDF), and $\mathrm{Ni}$ foam, were purchased from Shenyang Kejing. Catalysts, including $\mathrm{MnO}_{2}, \mathrm{La}_{2} \mathrm{O}_{3}, \mathrm{SrO}$, and $\mathrm{ZnO}$, were from Sinopharm Chemical Reagent. Organic solvent $\mathrm{N}$-methyl pyrrolidone (NMP) was provided by Shanghai Hushi Laboratorial Equipment Co., Ltd. Al foil and $\mathrm{KOH}$ (from Chinasun Specialty Products Co., Ltd.) solution served as the metal anode and electrolyte, respectively.

\subsection{Fabrication of Al-air Batteries}

Air cathode was prepared according to the method used in our previous study [3], with conductive carbon materials, catalysts, binder, and current collector. A mixture of activated carbon $(70 \mathrm{~g})$, ether black (10 g), $\mathrm{MnO}_{2}(10 \mathrm{~g}), \mathrm{La}_{2} \mathrm{O}_{3}(8 \mathrm{~g})$, and $\mathrm{SrO}(2 \mathrm{~g})$ was milled together with PVDF $(8 \mathrm{~g})$ binder. Thereafter, the solid blend in NMP dispersed, forming a $400 \mathrm{ml}$ viscous paste, which was smeared evenly on the surface of the $\mathrm{Ni}$ foam and dried for $24 \mathrm{~h}$ at ambient temperature. A $0.3 \mathrm{~mm}$-thick cathode plate was obtained by pressing it at $8 \mathrm{MPa}$.

All experiments comprised $\mathrm{KOH}$ and $\mathrm{ZnO}$ aqueous alkaline solutions in distilled water as an electrolyte. $\mathrm{ZnO}$ additive in alkaline solutions was used as a corrosion inhibitor [3,5,29-33]. The concentrations of $\mathrm{KOH}$ and $\mathrm{ZnO}$ were $\alpha$ and $(\alpha / 30) \mathrm{wt} \%$ respectively. Al foil with $20 \mu \mathrm{m}$ thickness was used as the metal anode and cut into $6 \mathrm{~cm} \times 6 \mathrm{~cm}$, and the reaction area is a circle with a diameter of $4 \mathrm{~cm}$ and weight of $0.067 \mathrm{~g}$. The Al-air batteries were finally assembled, as shown in Figure 1 . The distance between the aluminum and air electrode is $6 \mathrm{~cm}$. 


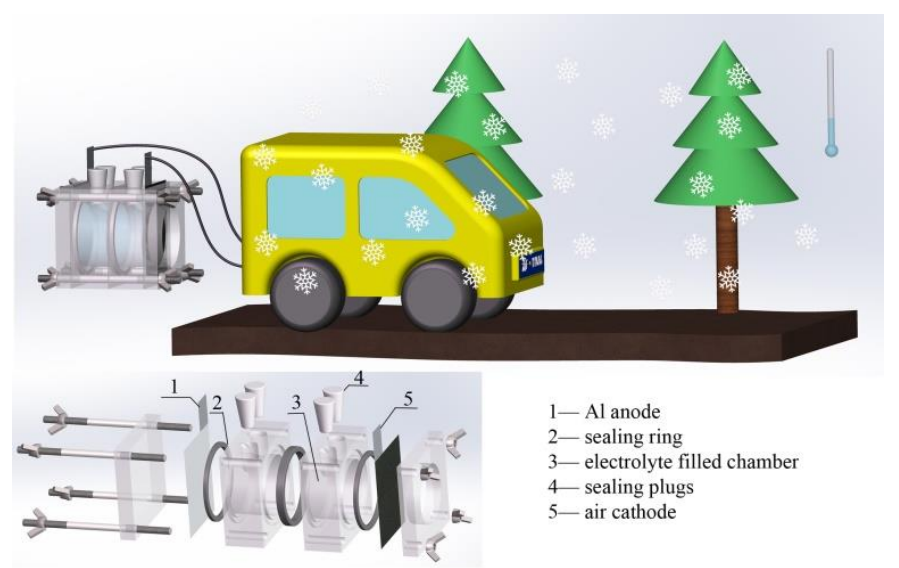

Figure 1. Schematic illustration of the assembled Al-air battery.

\subsection{Electrochemical Tests}

Conductivity is one of the most important factors that affect electrochemical performance. Different contents of $\mathrm{KOH}$ pellets were added into distilled water, and the conductivities were measured each time at different temperatures. A pair of Pt electrode was immersed in the electrolyte solution to measure the conductivity with a Mettler Toledo FE30 conductivity testing system. Discharge characteristics of the assembled Al-air batteries were measured using a LAND battery testing system at room, zero, and subzero temperatures. Once the cell was assembled, a $5 \mathrm{~min}$ period was left to allow good impregnation of electrodes to stabilize the open circuit potential. To characterize the self-discharge behavior, Tafel extrapolation was performed using an electrochemical workstation RST5000 in the conventional three-electrode cell. A Platinum wire was used as the counter electrode and mercury/mercuric oxide $(\mathrm{Hg} / \mathrm{HgO})$ was used as the reference electrode. The working electrode was the $\mathrm{Al}$ anode. After the $\mathrm{Al}$ anodes were immersed in electrolyte for $20 \mathrm{~min}$ to allow for potential stabilization; potentiodynamic polarization was conducted at a $1 \mathrm{mV} / \mathrm{s}$ scan rate. The voltage scan range of the anodic polarizing curve was -0.5 to $0.5 \mathrm{~V}$ vs. open circuit potential.

\section{Results and Discussion}

\subsection{Ionic Conductivity}

Figure 2 shows the conditions of $\mathrm{KOH}$ solution (with $\alpha=20,30$, and 40 concentration), which was kept frozen for $24 \mathrm{~h}$ at $-25^{\circ} \mathrm{C}$. Distilled water was also frozen for comparative purposes. As shown in the figure, the $\mathrm{KOH}$ solution at a low concentration $(20 \mathrm{wt} \%)$ was frozen, and the solution still flowed evenly at extremely LT at high concentrations. This finding illustrates well that $\mathrm{KOH}$ solution with concentration higher than $20 \mathrm{wt} \%$ could be adopted in Al-air battery at LT.

Figure 3 displays the conductivity of electrolyte solution (including $\mathrm{KOH}$ and $\mathrm{ZnO}$ ) in terms of the mass fraction of $\mathrm{KOH}$ and temperature. The conductivity decreases further with decreasing temperature. Conductivity decreases with increasing $\mathrm{KOH}$ content after the peak because of increased viscosity and restricted ion mobility [34-36]. The highest conductivity of around $560 \mathrm{mS} \mathrm{cm}^{-1}$ is observed at $\mathrm{KOH}$ content 31.5 at $15^{\circ} \mathrm{C}$. Fairly high conductivity of $230 \mathrm{mS} \mathrm{cm}^{-1}$ with content $28 \mathrm{wt} \%$ is evident when the temperature is lowered to $-15^{\circ} \mathrm{C}$. The $\mathrm{KOH}$ content is fixed at 25 and $31 \mathrm{wt} \%$ $(\alpha=25$ and 31) in the following research. 


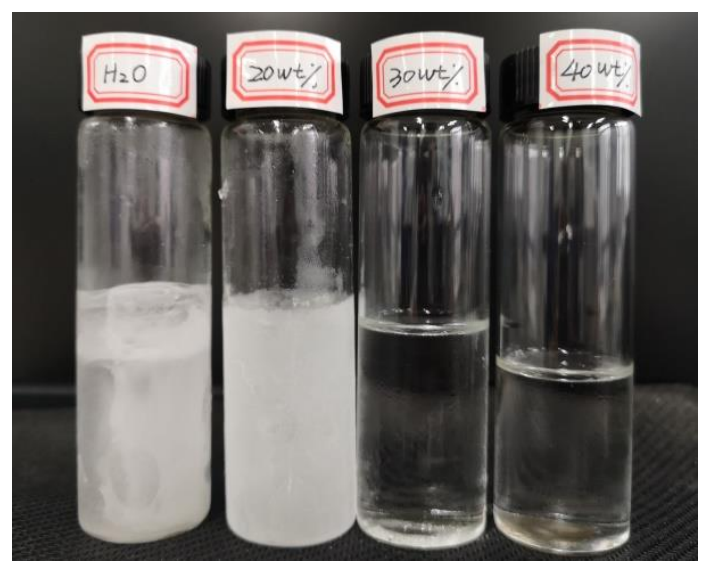

Figure 2. Photographs of $\mathrm{KOH}$ at different concentrations after being frozen for $24 \mathrm{~h}$ at $-25^{\circ} \mathrm{C}$. Pure water on the left is used for comparison.

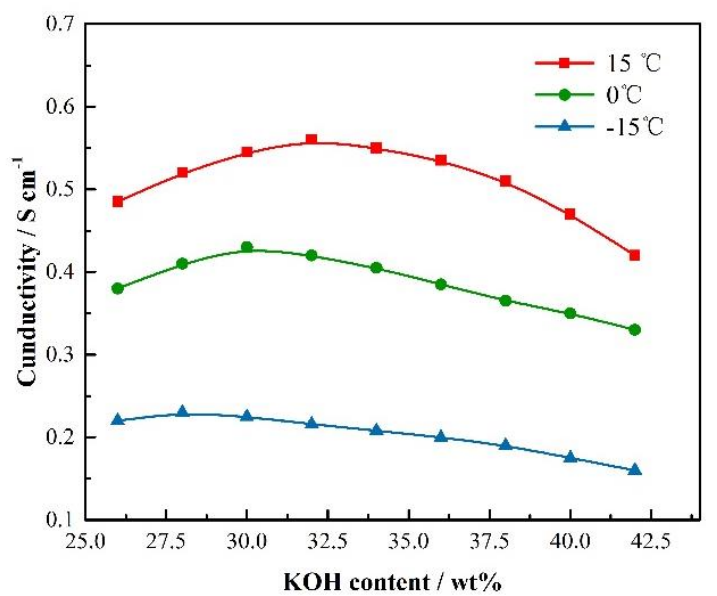

Figure 3. Conductivity curve of $\mathrm{KOH}$ at different concentrations and temperatures.

\subsection{Electrochemical Characterization}

Figure 4 shows the discharge behaviors of the $\mathrm{Al}$-air battery using $25 \mathrm{wt} \% \mathrm{KOH}$ electrolyte solution at constant current densities of $0.5 \mathrm{~mA} \mathrm{~cm}^{-2}$ (a) and $1.0 \mathrm{~mA} \mathrm{~cm}^{-2}$ (b). The result shows that the Al-air battery at $0{ }^{\circ} \mathrm{C}$ exhibits an open-circuit voltage of $1.41 \mathrm{~V}$, which is higher than that of other temperatures, whereas the lowest open-circuit and platform voltage appeared at $-15^{\circ} \mathrm{C}$. The cathode reaction would be affected by the diffusion coefficient of oxygen. According to Arrhenius-type equation [37], the gas diffusion coefficient decreases with temperature. However, proper LT would inhibit the hydrogen evolution of $\mathrm{Al}$ anode. Additionally, the discharge time of the Al-air battery at $-15^{\circ} \mathrm{C}$ is unexpectedly up to $25 \mathrm{~h}$. The discharge time is related to the utilization of $\mathrm{Al}$ foil. The hydrogen generation was barely observed at $-15^{\circ} \mathrm{C}$, thereby indicating that the LT improves the stability of the Al-air battery and suppresses the parasitic reaction. At a discharge current density of $0.5 \mathrm{~mA} \mathrm{~cm}^{-2}$ (Figure $4 \mathrm{a}$ ), the Al-air battery achieves a capacity of $116 \mathrm{mAh} / \mathrm{g}$ at $25^{\circ} \mathrm{C}$, which is only $4.03 \%$ of aluminum's theoretical capacity ( $2980 \mathrm{mAh} / \mathrm{g}$ [38]), and the gravimetric energy density is $142 \mathrm{Wh} / \mathrm{g}$. At $-15^{\circ} \mathrm{C}, \mathrm{Al}$-air battery exhibited a much superior capacity of $2343 \mathrm{mAh} / \mathrm{g}$ at the same current density, which is $78.68 \%$ of the theoretical value. The gravimetric energy density is $2480 \mathrm{Wh}$ $\mathrm{g}^{-1}$. Compared with the current density $0.5 \mathrm{~mA} \mathrm{~cm}^{-2}$ case, the capacity increases by $1.12,1.84$, and 2.175 folds at $-15^{\circ} \mathrm{C}, 0{ }^{\circ} \mathrm{C}$, and $15^{\circ} \mathrm{C}$, respectively, at $1.0 \mathrm{~mA} \mathrm{~cm}^{-2}$ (Figure $4 \mathrm{~b}$ ). The conductivity of electrolyte is essential for the discharge performance. LT results in the reduction $\mathrm{OH}^{-}$activity, which also improves the oxygen reduction reactions. The extraordinary capacity is mainly due to the effect of LT on the anodic reaction. 

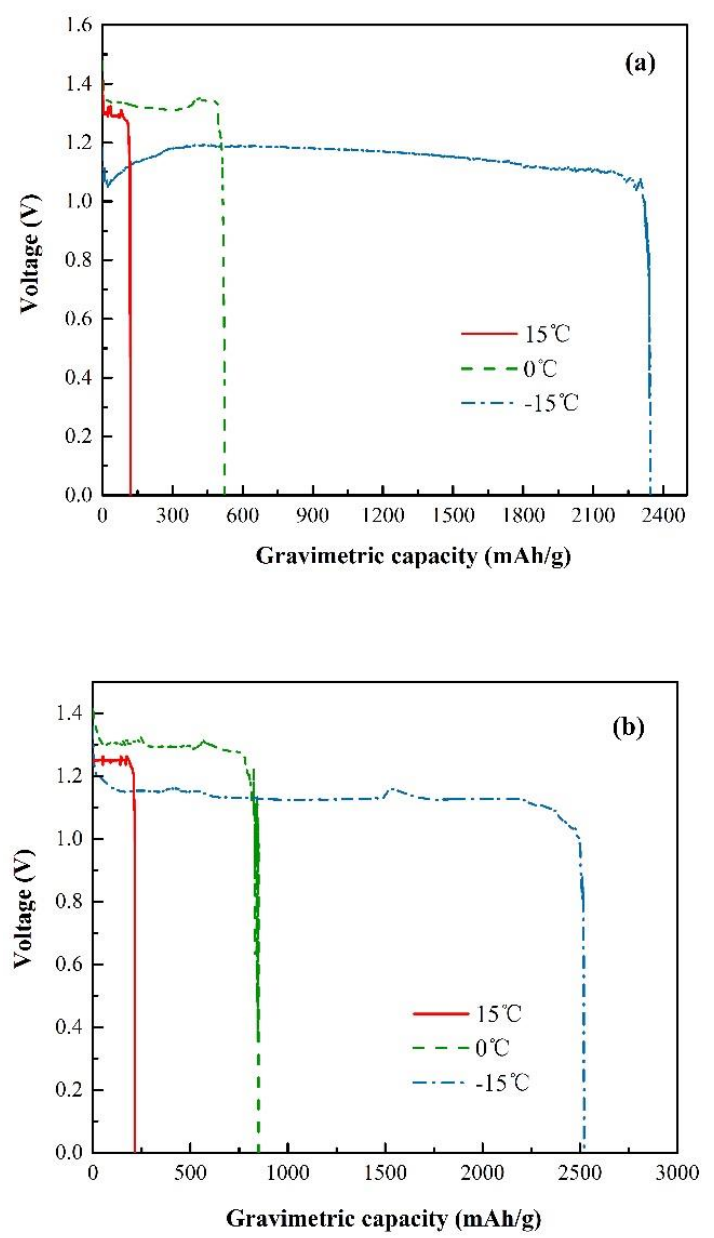

Figure 4. Discharging voltage profiles with a constant current density of $0.5 \mathrm{~mA} \mathrm{~cm}{ }^{-2}$ : (a) and $1.0 \mathrm{~mA} \mathrm{~cm}{ }^{-2} ;(\mathbf{b})$ by using $25 \mathrm{wt} \% \mathrm{KOH}$.

The discharging performances are also tested using a higher concentration (31 $\mathrm{wt} \%$ ) $\mathrm{KOH}$ electrolyte solution with constant current densities of 0.5 and $1.0 \mathrm{~mA} \mathrm{~cm}^{-2}$. With increasing electrolyte concentration, the Al-air battery achieves high discharge voltage but low capacities, as shown in Figure 5. When the electrolyte concentration is high, the aluminum oxidation rate increases. Therefore, the batteries exhibit high discharge voltage, short discharge time, and low capacities.

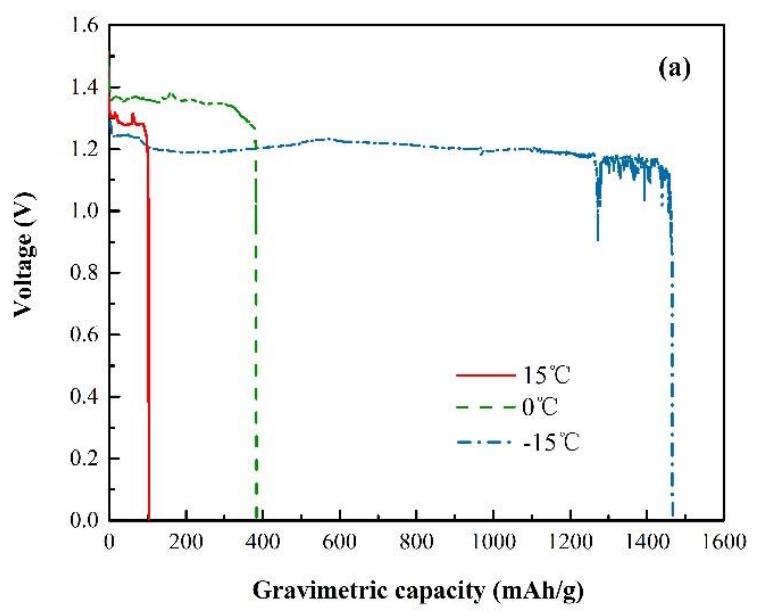

Figure 5. Cont. 


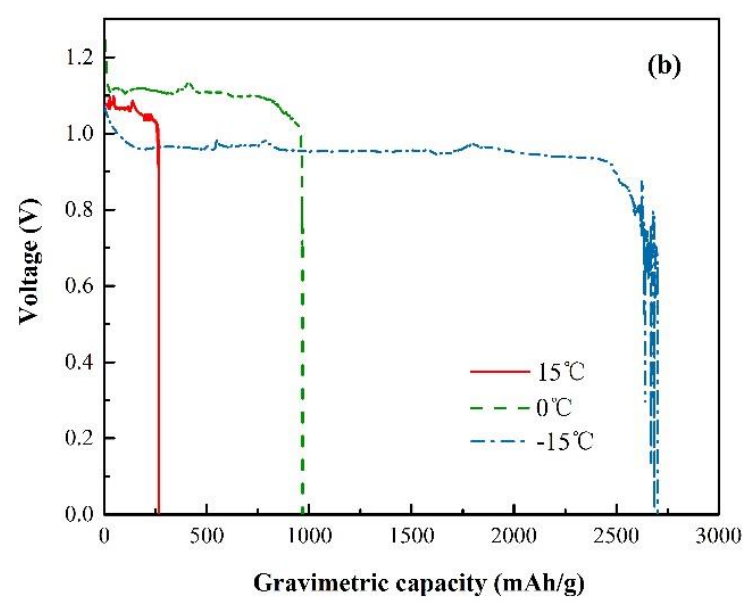

Figure 5. Discharging voltage profiles with a constant current density of $0.5 \mathrm{~mA} \mathrm{~cm}^{-2}$ : (a) and $1.0 \mathrm{~mA}$ $\mathrm{cm}^{-2}$; (b) by using $31 \mathrm{wt} \% \mathrm{KOH}$.

The potentiodynamic polarization at different temperatures was measured using a three-electrode system. Figure 6 and Table 1 respectively present the Tafel curves and corresponding corrosion parameters of $\mathrm{Al}$ anodes in $25 \mathrm{wt} \% \mathrm{KOH}$ (Figure $6 \mathrm{a}$ ) and $31 \mathrm{wt} \% \mathrm{KOH}$ (Figure $6 \mathrm{~b}$ ) electrolyte solutions. The values of the corrosion potential $\left(E_{\text {corr }}\right)$ and the corrosion current density $\left(I_{c o r r}\right)$ are calculated from the Tafel plots. The corrosion inhibition efficiency is calculated by the following formula as used in Reference [39-41].

$$
\eta \%=\frac{I_{\text {corr }}-I_{\text {corr }(\text { inh })}}{I_{\text {corr }}} \times 100,
$$

where the $I_{\text {corr }}$ and $I_{\text {corr }(i n h)}$ are the corrosion current densities at $15{ }^{\circ} \mathrm{C}$ and other temperatures, respectively. Based on the Tafel plot results, the corrosion current density of $\mathrm{Al}$-air batteries at $15^{\circ} \mathrm{C}$ is clearly much larger than that of 0 or $-15^{\circ} \mathrm{C}$, and the corrosion potential shifts, implying that it is less corrosion resistant and possesses the largest self-corrosion rate than that of others. As illustrated in Table 1, the inhibition efficiencies are much high at LT. The largest inhibition efficiency is obtained at $-15{ }^{\circ} \mathrm{C}$. This finding further confirms the discharged behaviors in Figures 4 and 5 . The LT can significantly prevent the corrosion of aluminum anodes in $\mathrm{KOH}$ electrolyte solution.

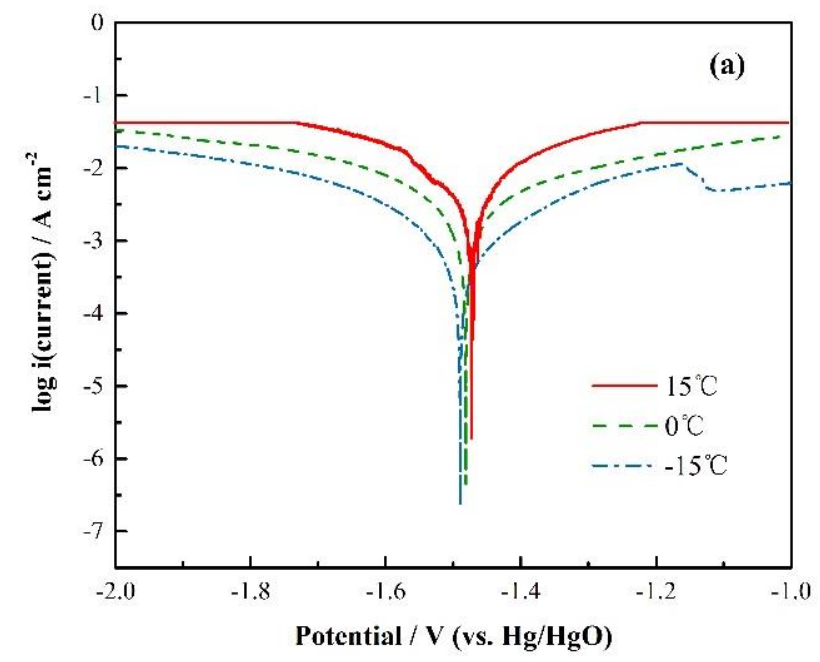

Figure 6. Cont. 


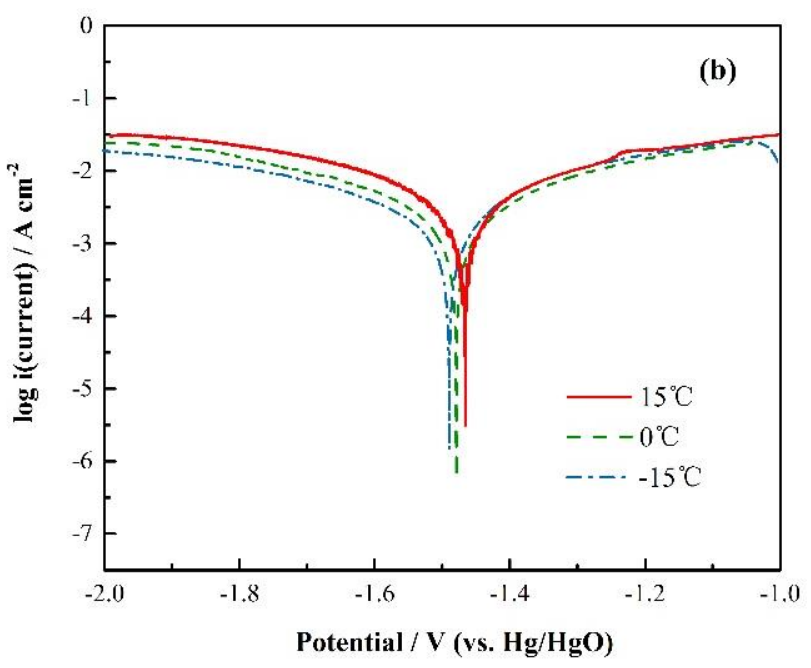

Figure 6. Potentiodynamic polarization curves for $\mathrm{Al}$ anodes measured in $25 \mathrm{wt} \% \mathrm{KOH}$ : (a) and 31 $\mathrm{wt} \% \mathrm{KOH} ;(\mathbf{b})$ at different temperatures.

Table 1. Corrosion parameters of $\mathrm{Al}$ anodes in $\mathrm{KOH}$ electrolyte at different temperatures.

\begin{tabular}{ccccc}
\hline KOH Content & Temperature $\left({ }^{\circ} \mathbf{C}\right)$ & $-\mathbf{E}_{\text {corr }}(\mathrm{V}$ vs. $\mathbf{H g} / \mathbf{H g O})$ & $\mathbf{I}_{\text {corr }}\left(\mathbf{m A} / \mathbf{c m}^{2}\right)$ & $\eta \%$ \\
\hline \multirow{2}{*}{$25 \mathrm{wt} \%$} & -15 & -1.490 & 0.232 & 84.33 \\
& 0 & -1.480 & 0.695 & 53.02 \\
$31 \mathrm{wt} \%$ & 15 & -1.471 & 1.479 & - \\
& -15 & -1.487 & 0.448 & 44.54 \\
& 0 & -1.479 & 0.534 & 33.86 \\
\hline
\end{tabular}

For further evaluation of the impacts of ambient temperature on Al-air battery, their current-voltage/current-power curves in $25 \mathrm{wt} \%$ and $31 \mathrm{wt} \% \mathrm{KOH}$ are shown in Figure $7 \mathrm{a}, \mathrm{b}$, respectively. The voltages ranged between 1550 and $350 \mathrm{mV}$, with an applied discharge current density in the range of $0.5-170 \mathrm{~mA} \mathrm{~cm}^{-2}$. With increasing current density, the discharge voltage decreased accordingly. The batteries at $0^{\circ} \mathrm{C}$ showed higher power density than that of others. The Al-air batteries with $25 \mathrm{wt} \% \mathrm{KOH}$ electrolyte reached the peak value of $101.14 \pm 2.8 \mathrm{~mW} \mathrm{~cm}^{-2}\left(0^{\circ} \mathrm{C}\right)$ at $130 \mathrm{~mA} \mathrm{~cm}{ }^{-2}$, which is higher than that of $92.17 \pm 2.6 \mathrm{~mW} \mathrm{~cm}^{-2}\left(15^{\circ} \mathrm{C}\right)$ and $80.21 \pm 2.8 \mathrm{~mW} \mathrm{~cm}^{-2}\left(-15^{\circ} \mathrm{C}\right)$, as depicted in Figure 7a. For cases of high electrolyte solution concentrations (31 wt $\%$ ), the discharge voltages and power densities increase, as plotted in Figure $7 \mathrm{~b}$. The maximum power densities reach $104 \pm 2.9 \mathrm{~mW} \mathrm{~cm}^{-2}\left(0^{\circ} \mathrm{C}\right)$ at $130 \mathrm{~mA} \mathrm{~cm}^{-2}$, which is more than $95.55 \pm 2.7 \mathrm{~mW} \mathrm{~cm}^{-2}\left(15^{\circ} \mathrm{C}\right)$ and $84.37 \pm 2.6 \mathrm{~mW} \mathrm{~cm}^{-2}\left(-15^{\circ} \mathrm{C}\right)$. These data provide rather surprising results, thereby suggesting that the proper LT improves the power density of Al-air battery. Although the LT environment lowered the electrical conductivity of electrolyte solution, LT repressed the hydrogen evolution reaction and promoted oxygen reduction reactions to a certain degree. 

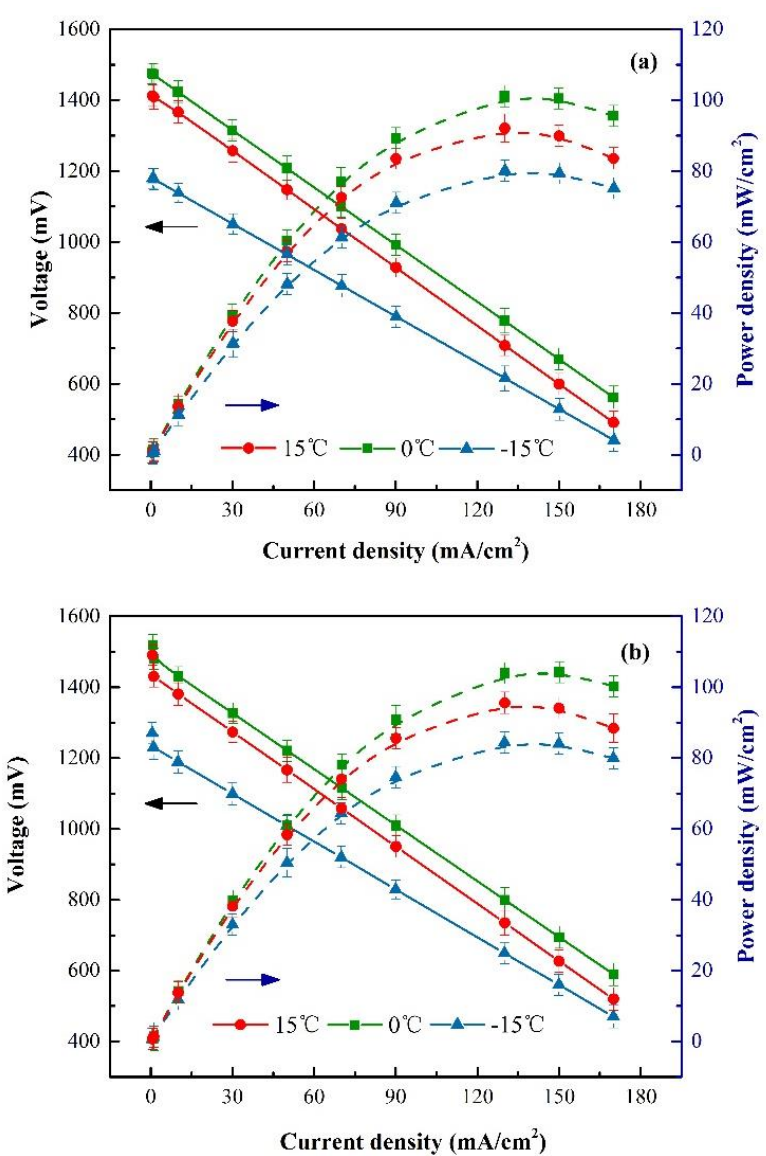

Figure 7. Discharging voltage and power density profiles versus current density with $25 \mathrm{wt} \%$ : (a) and $31 \mathrm{wt} \%$; (b) $\mathrm{KOH}$ electrolyte solutions.

\section{Conclusions}

Measurements for LT electrochemical performance of Al-air batteries are reported for the first time. The combination effects of temperature and electrolyte concentrations on electrochemical performance are discussed. Different temperatures are included for comparison. The LT has a significant effect on the discharge performance. In the tests of constant current discharge, the capacities of Al-air batteries can reach $2343 \mathrm{mAh} / \mathrm{g}$ with $25 \mathrm{wt} \% \mathrm{KOH}$ electrolyte and $2480 \mathrm{mAh} / \mathrm{g}$ with $31 \mathrm{wt} \% \mathrm{KOH}$ electrolyte at $-15{ }^{\circ} \mathrm{C}$. The corrosion experiments of $\mathrm{Al}$ anodes further demonstrate that the LT could effectively decrease the hydrogen evolution reaction. Surprisingly, the $\mathrm{Al}$-air batteries at $0{ }^{\circ} \mathrm{C}$ exhibit high discharge voltage and power densities. The peak value of power densities at $0^{\circ} \mathrm{C}$ reaches 101.14 $\pm 2.8 \mathrm{~mW} \mathrm{~cm}^{-2}(25 \mathrm{wt} \% \mathrm{KOH})$ and $104 \pm 2.9 \mathrm{~mW} \mathrm{~cm}{ }^{-2}(31 \mathrm{wt} \% \mathrm{KOH})$ at $130 \mathrm{~mA} \mathrm{~cm}^{-2}$, which is higher than that of $-15^{\circ} \mathrm{C}$ and $15^{\circ} \mathrm{C}$. Therefore, the proper LT could improve the performance of $\mathrm{Al}$-air batteries. This novel result is crucial to studies focusing on power sources for wide temperature ranges. Further studies on the improvement of LT of metal-air battery are needed.

Author Contributions: Conceptualization, Y.Z., Y.Y. and C.Z.; writing-original draft preparation, Y.Z. and Y.Y.; writing-review and editing, C.N., H.L., Z.G. and C.S.; supervision, C.Z. and Q.C.

Funding: This research was funded by the National Natural Science Foundation of China (grant number 51775242 and 11802102), and the Zhejiang Provincial Natural Science Foundation (grant number LY19A020006 and LQ19E020003).

Conflicts of Interest: The authors declare no conflict of interest. 


\section{References}

1. Wang, Z.L.; Xu, D.; Zhong, H.X.; Wang, J.; Meng, F.L.; Zhang, X.B. Gelatin-derived sustainable carbon-based functional materials for energy conversion and storage with controllability of structure and component. Sci. Adv. 2015, 1, e1400035. [CrossRef]

2. Gai, W.Z.; Deng, Z.Y. Effect of trace species in water on the reaction of Al with water. J. Power Sources 2014, 245, 721-729. [CrossRef]

3. Zhang, Z.; Zuo, C.; Liu, Z.; Yu, Y.; Zuo, Y.; Song, Y. All-solid-state Al-air batteries with polymer alkaline gel electrolyte. J. Power Sources 2014, 251, 470-475. [CrossRef]

4. Hopkins, B.J.; Shao-Horn, Y.; Hart, D.P. Suppressing corrosion in primary aluminum-air batteries via oil displacemen. Science 2018, 362, 658-661. [CrossRef] [PubMed]

5. Gelman, D.; Lasman, I.; Elfimchev, S.; Starosvetsky, D.; Ein-Eli, Y. Aluminum corrosion mitigation in alkaline electrolytes containing hybrid inorganic/organic inhibitor system for power sources applications. J. Power Sources 2015, 285, 100-108. [CrossRef]

6. Fan, L.; Lu, H.; Leng, J. Performance of fine structured aluminum anodes in neutral and alkaline electrolytes for Al-air batteries. Electrochim. Acta 2015, 165, 22-28. [CrossRef]

7. Grande, L.; Paillard, E.; Hassoun, J.; Park, J.B.; Lee, Y.J.; Sun, Y.K.; Passerini, S.; Scrosati, B. The lithium/air battery: Still an emerging system or a practical reality? Adv. Mater. 2015, 27, 784-800. [CrossRef] [PubMed]

8. Zhang, S.S.; Xu, K.; Jow, T.R. Electrochemical impedance study on the low temperature of Li-ion batteries. Electrochim. Acta 2004, 49, 1057-1061. [CrossRef]

9. Li, Q.; Li, Z.; Zhang, Z.; Li, C.; Ma, J.; Wang, C.; Ge, X.; Dong, S.H.; Yin, L. Low-Temperature Solution-Based Phosphorization Reaction Route to Sn4P3/Reduced Graphene Oxide Nanohybrids as Anodes for Sodium Ion Batteries. Adv. Energy Mater. 2016, 6, 1600376. [CrossRef]

10. Qi, Y.; Mu, L.; Zhao, J.; Hu, Y.S.; Liu, H.; Dai, S. Superior Na-Storage Performance of Low-Temperature-Synthesized $\mathrm{Na}_{3}\left(\mathrm{VO}_{1-x} \mathrm{PO}_{4}\right)_{2} \mathrm{~F}_{1+2 x}(0 \leq x \leq 1)$ Nanoparticles for Na-Ion Batteries. Angew. Chem. Int. Ed. 2015, 54, 9911-9916. [CrossRef] [PubMed]

11. Zhu, G.; Wen, K.; Lv, W.; Zhou, X.; Liang, Y.; Yang, F.; Chen, Z.; Zou, M.; Li, J.; Zhang, Y.; et al. Materials insights into low-temperature performances of lithium-ion batteries. J. Power Sources 2015, 300, $29-40$. [CrossRef]

12. Shang, H.; Zuo, Z.; Yu, L.; Wang, F.; He, F.; Li, Y. Low-Temperature Growth of All-Carbon Graphdiyne on a Silicon Anode for High-Performance Lithium-Ion Batteries. Adv. Mater. 2018, 30, 1801459. [CrossRef] [PubMed]

13. Wang, Y.Y.; Hou, B.H.; Guo, J.Z.; Ning, Q.L.; Pang, W.L.; Wang, J.; Lü, C.L.; Wu, X.L. An Ultralong Lifespan and Low-Temperature Workable Sodium-Ion Full Battery for Stationary Energy Storage. Adv. Energy Mater. 2018, 8, 1703252. [CrossRef]

14. Ji, Y.; Zhang, Y.; Wang, C.Y. Li-ion cell operation at low temperatures. J. Electrochem. Soc. 2013, 160, A636-A649. [CrossRef]

15. Mousa, A.; Skyllas-Kazacos, M. Effect of additives on the low-temperature stability of vanadium redox flow battery negative half-cell electrolyte. ChemElectroChem 2015, 2, 1742-1751. [CrossRef]

16. You, Y.; Yao, H.R.; Xin, S.; Yin, Y.X.; Zuo, T.T.; Yang, C.P.; Guo, Y.-G.; Cui, Y.; Wan, L.-J.; Goodenough, J.-B. Subzero-Temperature Cathode for a Sodium-Ion Battery. Adv. Mater. 2016, 28, 7243-7248. [CrossRef] [PubMed]

17. Senyshyn, A.; Mühlbauer, M.J.; Dolotko, O.; Ehrenberg, H. Low-temperature performance of Li-ion batteries: The behavior of lithiated graphite. J. Power Sources 2015, 282, 235-240. [CrossRef]

18. Lee, M.J.; Lho, E.; Bai, P.; Chae, S.; Li, J.; Cho, J. Low-temperature carbon coating of nanosized Li1. $015 \mathrm{Al0.}$ 06Mn1. $925 \mathrm{O} 4$ and high-density electrode for high-power Li-Ion batteries. Nano Lett. 2017, 17, 3744-3751. [CrossRef]

19. Jaguemont, J.; Boulon, L.; Dubé, Y. A comprehensive review of lithium-ion batteries used in hybrid and electric vehicles at cold temperatures. Appl. Energy 2016, 164, 99-114. [CrossRef]

20. Smart, M.C.; Ratnakumar, B.V.; Chin, K.B.; Whitcanack, L.D. Lithium-ion electrolytes containing ester cosolvents for improved low temperature performance. J. Electrochem. Soc. 2010, 157, A1361-A1374. [CrossRef]

21. Sides, C.R.; Martin, C.R. Nanostructured Electrodes and the Low-Temperature Performance of Li-Ion Batteries. Adv. Mater. 2005, 17, 125-128. [CrossRef] 
22. Zhang, S.S.; Xu, K.; Jow, T.R. A new approach toward improved low temperature performance of Li-ion battery. Electrochem. Commun. 2002, 4, 928-932. [CrossRef]

23. Liu, J.; Lin, X.; Han, T.; Li, X.; Gu, C.; Li, J. A novel litchi-like LiFePO4 sphere/reduced graphene oxide composite Li-ion battery cathode with high capacity, good rate-performance and low-temperature property. Appl. Surf. Sci. 2018, 459, 233-241. [CrossRef]

24. Tripathy, Y.; McGordon, A.; Low, C. A New Consideration for Validating Battery Performance at Low Ambient Temperatures. Energies 2018, 11, 2439. [CrossRef]

25. Li, Y.; Qian, K.; He, Y.B.; Kaneti, Y.V.; Liu, D.; Luo, D.; Li, H.; Li, B.; Kang, F. Study on the reversible capacity loss of layered oxide cathode during low-temperature operation. J. Power Sources 2017, 342, 24-30. [CrossRef]

26. Wang, H.; Zhang, H.; Cheng, Y.; Feng, K.; Li, X.; Zhang, H. All-NASICON LVP-LTP aqueous lithium ion battery with excellent stability and low-temperature performance. Electrochim. Acta 2018, 278, 279-289. [CrossRef]

27. Reyes, J.R.M.D.; Parsons, R.V.; Hoemsen, R. Winter happens: The effect of ambient temperature on the travel range of electric vehicles. IEEE Trans. Veh. Technol. 2016, 65, 4016-4022. [CrossRef]

28. Inoishi, A.; Nishio, A.; Yoshioka, Y.; Kitajou, A.; Okada, S. A single-phase all-solid-state lithium battery based on $\mathrm{Li}_{1.5} \mathrm{Cr}_{0.5} \mathrm{Ti}_{1.5}\left(\mathrm{PO}_{4}\right)_{3}$ for high rate capability and low temperature operation. Chem. Commun. 2018, 54, 3178-3181. [CrossRef] [PubMed]

29. Zaromb, S. The use and behavior of aluminum anodes in alkaline primary batteries. J. Electrochem. Soc. 1962, 109, 1125-1130. [CrossRef]

30. Patnaik, R.S.M.; Ganesh, S.; Ashok, G.; Ganesan, M.; Kapali, V. Heat management in aluminium/air batteries: Sources of heat. J. Power Sources 1994, 50, 331-342. [CrossRef]

31. Li, Q.; Bjerrum, N.J. Aluminum as anode for energy storage and conversion: A review. J. Power Sources 2002, 110, 1-10. [CrossRef]

32. Gaikwad, A.M.; Whiting, G.L.; Steingart, D.A.; Arias, A.C. Highly flexible, printed alkaline batteries based on mesh-embedded electrodes. Adv. Mater. 2011, 23, 3251-3255. [CrossRef] [PubMed]

33. Mokhtar, M.; Majlan, E.H.; Ahmad, A.; Tasirin, S.M.; Daud, W.R.W. Effect of ZnO filler on PVA-alkaline solid polymer electrolyte for aluminum-air battery applications. J. Electrochem. Soc. 2018, 165, A2483-A2492. [CrossRef]

34. Yashonath, S.; Ghorai, P.K. Diffusion in nanoporous phases: Size dependence and levitation effect. J. Phys. Chem. B 2008, 112, 665-686. [CrossRef] [PubMed]

35. Ng, P.L.; Jamaludin, A.; Alias, Y.; Basirun, W.J.; Ahmad, Z.A.; Mohamad, A.A. Effect of KOH concentration in the gel polymer electrolyte for direct borohydride fuel cell. J. Appl. Polym. Sci. 2001, 123, 2662-2666. [CrossRef]

36. Iwakura, C.; Nohara, S.; Furukawa, N.; Inoue, H. The possible use of polymer gel electrolytes in nickel $/ \mathrm{metal}$ hydride battery. Solid State Ionics 2002, 148, 487-492. [CrossRef]

37. Lloyd, J.; Taylor, J.A. On the temperature dependence of soil respiration. Funct. Ecol. 1994, 8, 315-323. [CrossRef]

38. Elia, G.A.; Marquardt, K.; Hoeppner, K.; Fantini, S.; Lin, R.; Knipping, E.; Peters, W.; Drillet, J.-F.; Passerini, S.; Hahn, R. An overview and future perspectives of aluminum batteries. Adv. Mater. 2016, 28, 7564-7579. [CrossRef] [PubMed]

39. Jo, Y.N.; Kang, S.H.; Prasanna, K.; Eom, S.W.; Lee, C.W. Shield effect of polyaniline between zinc active material and aqueous electrolyte in zinc-air batteries. Appl. Surf. Sci. 2017, 422, 406-412. [CrossRef]

40. Migliardini, F.; Di Palma, T.M.; Gaele, M.F.; Corbo, P. Solid and acid electrolytes for Al-air batteries based on xanthan-HCl hydrogels. J. Solid State Electrochem. 2018, 22, 2901-2916. [CrossRef]

41. Kang, Q.X.; Wang, Y.; Zhang, X.Y. Experimental and theoretical investigation on calcium oxide and L-aspartic as an effective hybrid inhibitor for aluminum-air batteries. J. Alloys Compd. 2019, 774, 1069-1080. [CrossRef]

(C) 2019 by the authors. Licensee MDPI, Basel, Switzerland. This article is an open access article distributed under the terms and conditions of the Creative Commons Attribution (CC BY) license (http:/ / creativecommons.org/licenses/by/4.0/). 